Баранова Альбина Алексеевна, к.т.н., доцент, Ангарский государственный технический университет, e-mail: baranova2012aa@mail.ru

Язина Ольга Игоревна, магистрант, Ангарский государственный технический университет, e-mail: olya_94.07@mail.ru

Боброва Анна Александровна, обучающийся, Ангарский государственный технический университет

Рудых Кристина Николаевна,

обучающийся, Ангарский государственный технический университет, e-mail: rudykh_94@mail.ru

ВЛИЯНИЕ КОЛИЧЕСТВА МИКРОКРЕМНЕЗЁМА НА КОЭФФИЦИЕНТЫ КОНСТРУКТИВНОГО КАЧЕСТВА МЕЛКОЗЕРНИСТОГО БЕТОНА И КОНСТРУКЦИОННОГО ПЕНОБЕТОНА

Baranova A.A., Yazina O.I., Bobrova A.A., Rudykh K.N.

\title{
EFFECT OF QUANTITY OF SILICA FUME ON THE COEFFICIENTS OF CONSTRUCTIVE QUALITY FINE-GRAINED CONCRETE AND STRUCTURAL FOAM CONCRETE
}

\begin{abstract}
Аннотация. В статье приведены коэффициенты конструктивного качества мелкозернистого бетона и конструкционного пенобетона с разным процентным содержанием микрокремнезёма в смеси.
\end{abstract}

Ключевые слова: коэффициент конструктивного качества, микрокремнезём, пенобетон, мелкозернистый бетон.

Abstract. The article presents the coefficients of the constructive quality of fine-grained concrete and structural foam concrete with different percentages of micro-silica in the mixture.

Keywords: coefficient of the constructive quality, microsilica, foam concrete, fine-grained concrete.

Мелкозернистый бетон отличается от пенобетона только лишь отсутствием пены в смеси или пенообразователя в составе. Поэтому можно допустить, что мелкозернистый бетон является невспененной матрицей пенобетона.

Целью данной работы является исследование влияние количества микрокремнезёма на прочностные характеристики мелкозернистого бетона и конструкционного пенобетона.

В исследованиях использовались следующие материалы: белый цемент фрирмы Chimsa CEM I 52,5 R (ПЦ 600) производства Турции, цемент марки ЦЕМ II/A-3 32,5Б (ПЦ 400 Д20) производства АО «Ангарскцемент», микрокремнезём с

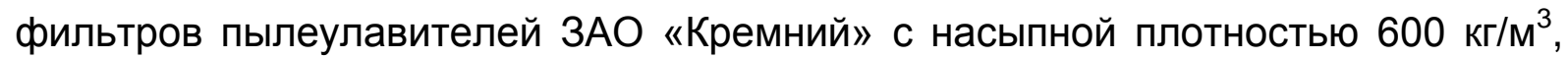
гиперпластификатор на основе поликарбоксилатов «MC-Power-Flow-3100», синтетический пенообразователь Пента Пав 430А.

Замесы бетонов производились вручную. Количество микрокремнезёма в составах варьировалось от 50 \% до 70 \% от массы сухих веществ. Марка по 
плотности пенобетона составляла D900 $\div$ D1000, средняя плотность

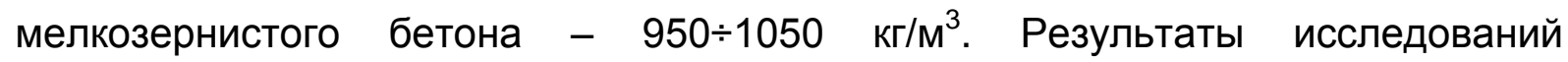
представлены в таблице 1.

Таблица 1

Зависимость коэфффициентов конструктивного качества (К.К.К.) конструкционного пенобетона и мелкодисперсного бетона от соотношения твёрдых компонентов смеси

\begin{tabular}{|c|c|c|c|c|}
\hline \multirow{2}{*}{$\begin{array}{l}\text { № } \\
\text { п/п }\end{array}$} & \multicolumn{3}{|c|}{$\begin{array}{c}\text { Содержание твёрдых компонентов смеси, } \\
\% \text { по массе }\end{array}$} & \multirow[t]{2}{*}{ К.К.К. $=\mathrm{R}_{\mathrm{c} \psi} / \rho_{\mathrm{cp}}$} \\
\hline & ПЦ 400 Д20 & ПЦ 600 & Микрокремнезём & \\
\hline \multicolumn{5}{|c|}{ Конструкционный пенобетон } \\
\hline 1 & 30 & - & 70 & 13,38 \\
\hline 2 & 40 & - & 60 & 18,07 \\
\hline 3 & 50 & - & 50 & 10,32 \\
\hline 4 & - & 30 & 70 & 28,06 \\
\hline 5 & - & 40 & 60 & 22,57 \\
\hline 6 & - & 50 & 50 & 12,74 \\
\hline \multicolumn{5}{|c|}{ Мелкозернистый бетон } \\
\hline 7 & 30 & - & 70 & 9,89 \\
\hline 8 & 40 & - & 60 & 14.97 \\
\hline 9 & 50 & - & 50 & 15,15 \\
\hline 10 & - & 30 & 70 & 12,76 \\
\hline 11 & - & 40 & 60 & 13,48 \\
\hline 12 & - & 50 & 50 & 19,50 \\
\hline
\end{tabular}

Из таблицы 1 видно, что увеличение количества микрокремнезёма в составе конструкционного пенобетона приводит к росту коэффицциента конструктивного качества. Для мелкозернистого бетона, напротив, с увеличением количества микрокремнезёма К.К.К. снижается. Объясняется это тем, что благодаря низкой насыпной плотности микрокремнезёма увеличение его количества в пенобетонной смеси способствует утолщению межпоровых перегородок пенобетона и снижению его общей пористости. Таким образом, оптимальное содержание микрокремнезёма в составе мелкозернистого бетона

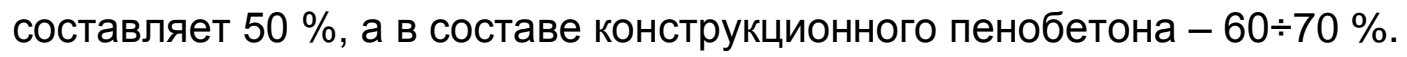

\section{ЛИТЕРАТУРА}

1. Баранова А.А., Боброва А.А., Рудых К.Н. Мелкодисперсный бетон для производства малых архитектурных форм // Современные технологии и научно-технический прогресс, 2017. - Т. 1. - С. 108-109.

2. Баранова А.А., Баденикова М.В., Боброва А.А., Рудых К.Н. Мелкозернистый бетон на основе микрокремнезёма // Вестник АнГТУ, 2017. - № 11. - С. 147-150. 